\title{
Local Government Communication in Indonesia: Observations from Banjarmasin, South Kalimantan
}

\author{
BACHRUDDIN ALI AKHMAD \\ Universitas Lambung Mangkurat, Indonesia
}

\begin{abstract}
Most studies of democratization in developing countries fail to link their analysis with the implementation of local government communication. As a consequence, the study of government communication is too elitist and central government-oriented. This study contributes to the study of government communication in the context of local governance for countries in a democratic transition. The authors use local government communication in public services in Banjarmasin City, South Kalimantan Province, Indonesia, as a case of observation. Using a qualitative approach to explore the complexity of cultural and structural factors, the authors combine the results of an analysis of various documents, observations and in-depth interviews relating to the practices of local government communication in South Kalimantan from January to June 2018. In conclusion, the results indicated that the quality of local government communication was influenced by various factors both cultural and structural. Although local cultural factors remain important, in the case of the South Kalimantan, structural factors have more influence on regional government communication. While regional government communication performance does not yet involve active participation from below, more elite-oriented than public-oriented. The regional government officers are less responsive and still topdown, so the ideas of professionalization of local government communications are still limited to expectations rather than reality. This study recommends that local government communication can be effective if it adopts a participatory government communication perspective by involving the key stakeholders and local people in participation in the planning and implementation of communication including women's voices and perspectives.
\end{abstract}

Keywords: Government communication, local democracy, decentralisation, participation, South Kalimantan.

\section{INTRODUCTION}

Dramatic changes in the Indonesian political landscape during the end of the New Order regime were considered a crucial prerequisite for local democratization in the entire archipelago. Decentralization policy has changed the local political landscape in Indonesia. At first, decentralization was intended to create good governance at the local level (Bünte \& Ufen, 2009). This policy has been supported by international institutions such as the World Bank and International Monetary Fund (IMF). The World Bank has even stated that decentralization is a "big bang" in Indonesian politics (Hofman \& Kaiser, 2002; Supriatma, 2009, p.10).

Decentralization in Indonesia has also been described as "less state, more democracy". According to an observer,

After the Asian monetary and political crisis of 1997 and 1998, which was followed by a period labelled as the reformation, Indonesia is viewed by some observers as having entered a transitional phase from authoritarian rule towards a new democratic system of government in which civil society will 
play a more prominent role. This transition is, moreover, accompanied by a process of decentralization that emphasizes regional autonomy and is expected to bring democracy to the people while making government more transparent (Nordholt, 2004, p. 29).

So far, the implementation practices and performance of local government were considered not always in line with the main objective of decentralization: responsive, transparent, accountable, and good local government (Aspinall \& Fealy, 2003; Rasyid, 2003). Highlighting outcomes of decentralization, Hadiz, for instance, conducted detailed case studies on the composition of local elites or subnational party dynamics. He exposed the political naïveté of many decentralization programs implemented as a part of broader development initiatives (Hadiz, 2010). Hadiz concluded that decentralization failed to fundamentally transform power relations in Indonesian local politics because the political forces of the Suharto period survived the regime collapse in 1998.

Although undemocratic practices are not new to Indonesian politics, from the optimistic side, decentralization still grows the seeds of hope. This hope arises in a new political culture that is more democratic and egalitarian even to the village level, so that power becomes increasingly dispersed and obtained in fair competition climate. The traditional mechanism of "Rembug Desa" in a village in West Java, for example, as a deliberative space to find solutions in resolving conflicts in the village involving village leaders and community members in a relatively equal position. This climate is very substantial and is needed when local democracy is to be used as a basis for good governance and communication in society (Prasetyo, 2010; Ibrahim, 2020, p. 140).

Most analyses have attempted to examine remarkable changes in the Indonesian political landscape since the era-Reformasi 1998, snapshots taken at the local level show an increasing gap between expectations and reality (Choi, 2004). Critics from the media and scholars were focused on the practices of government and local politics in Indonesia, for instances, the practice of corruption, money politics in elections, and even the practice of violence and cartels in the local political competition (Choi, 2004; Supriatma, 2009; Hadiz, 2010).

However, the analysis offers limited insight in assessing qualitative changes in local political and democratic practices in the archipelago as a whole, particularly those occurring beyond Java. These not only show how long Indonesian political studies have been dominated and centred on culture and politics in Java or Java-centered (see, for examples, Geertz, 1973; Jackson, 1978; Anderson, 1990; Hooker, 1993; Antlöv, 1995). But, at the same time, it also shows that something important is missing in the post-Suharto from accounts of Indonesia's democratization and decentralization: democratic government communication practices within local political institutions and institutionalized in local governments beyond Java.

In addition, studies that tend to focus on politics in Java, particularly the dynamics of national politics in Jakarta, the efforts of scholars have also been devoted to evaluating the effects of Indonesia's democratic transition that appear to have remained pitched at the battle of power, ideology, and political parties (Suryadinata, 2002; Buehler \& Tan, 2007; Mietzner, 2007; Tomsa, 2010; Ufen, 2011; Fionna, 2011; Buehler, 2012; Wahid, 2013; Madinier, 2015; Panuju, 2019). The same trend in some cases is also reflected in the development of Malaysian political studies (Hwang, 2010; Noor, 2014; Wan Norshira, 2019). These studies also show a narrow concern with local government communication and the scarcity of detailed studies of government communication in Indonesia and Malaysia. 
The decentralization of state institutions has been a global phenomenon for more than two decades. The decentralization of institutions in Indonesia has created different opportunity structures for political actors and parties in local politics, especially local government in formulating and implementing policies in the era of regional autonomy. Studying local government communication practices in relation to local democratization in post-Suharto Indonesia is an extraordinary challenge.

Decentralization policy in Indonesia concerning regional autonomy opens opportunities for regions beyond Java to manage governance independently, including in managing government communication. This also opens up opportunities for the growth of local democracy amidst the marginalization of the public sphere (Buehler, 2010). Local democracy is a cornerstone of a democratic society (Pratchett, 2004). According to Pratchett, seeing local democracy as a fundamental component of a broader participatory democracy has important consequences for the understanding and application of local autonomy (Pratchett, 2004).

This study is inspired by Canel and Sanders' (2003) challenges that despite its key importance for 21st-century politics, the study of government communication is an underresearched area of political communication studies. This study examines the outcomes of this trend in Banjarmasin, South Kalimantan, Indonesia, where the decentralization policies at the national level-shifted local powers and changed governance performance to the local level. Compared to other regions on the island of Kalimantan, South Kalimantan is unique. River culture and strong ties with ulama have shaped the character of their people who are independent and critical and influence their patterns of interaction in the economy and politics (Daud, 2004; Fatchiati, 2009). The central question in this article is: To which extent the local government communication involves the participation of its citizens?

\section{LITERATURE REVIEW}

Some scholars, such as Deutsch (1963), hold that politics is communication. In modern democracies, politicians and officeholders need communication as necessary "tool" in order to maintain its legitimacy. Government communication is a central feature of political life (Johansson \& Raunio, 2019). Because government communication "directed at the general public or particular groups in society. Hence, government communication belongs to the arena of political action." (Hansson, 2018, p. 326).

According to Canel and Sanders, government communication "refers to the aims, role and practice of communication implemented by executive politicians and officials of public institutions in the service of a political rationale, and that are themselves constituted based on the people's indirect or direct consent and are charged to enact their will" (Canel \& Sanders, 2011). This definition includes prime ministerial or presidential communication as well as mayoral or local and regional government communication. (Canel \& Sanders, 2012, pp. 85-86).

Canel and Sander view government communication "finding itself in a kind of theoretical no man's land between political communication, public relations and organizational communication research." Government communication is very important to ensure that government decisions and policies involve stakeholders and are in accordance with the needs and expectations of their citizens. As Canel and Sander suggest, "The quality of government matters for human well-being. Governing necessarily involves constant 
exchanges of information and communication about policies, ideas and decisions between governors and the governed." (Canel \& Sanders, 2003, p. 85).

Scholars who study government communication usually position themselves with the subject matter of their research from a different point of view. They conceptualise government communication in different ways. They focus their attention on different subject and research location. A more detailed review of the literature in these different streams of research reveals that government communication in modern democracies has been conceptualised by scholars in four competing ways: as a policy instrument, as a commodity, as manipulation, and as a factor in (un)doing democracy (Hansson, 2018, p. 328).

Contemporary research on government communication by Western scholars shows that their main emphasis is on top leaders and national governments. A review of much of the political communication literature shows that it is often used to refer solely to top-level executive communication at the presidential or prime ministerial level (Canel \& Sanders, 2012). Some American scholars have explored in depth the president's rhetoric and presidential communication strategy (Farnsworth, 2009; Coe \& Reitzes, 2010), presidential power and communication (Kernell, 1997), presidential relations with the media (Spragens, 2003; Walcott \& Hult, 2008), chief executive communication strategies in relation to political scandals and terrorism (Canel \& Sanders, 2010). In line with research that explains government communication as used in top-level and national-level executive communication, Australian scholar, Young (2007) has produced perhaps the most comprehensive countrybased overview of government communication (Canel \& Sanders, 2013).

Most recent studies also show relatively similar tendencies, for example, "trends in government communication" (Vos \& Westerhoudt, 2008); "comparative study on how governments communicate with citizens in different countries" (Sanders, Canel, \& HoltzBacha, 2011; Sanders, \& Canel, 2013); "discursive strategies in government" and "administrative language" (Hansson, 2015 \& 2017); "strategic communication of central government organizations" (Salomonsen, Frandsen, \& Johansen, 2016); "personalization of ministerial communication" (Figenschou, Karlsen, Kolltveit, \& Thrbjørnsrud, 2017). Indeed, the vast majority of political communication research centred on government communication has tended to examine themes such as media management and officeholders' rhetoric exclusively in relation to the senior national government. But government communication can also be used to refer to communication undertaken by executive institutions at regional and local levels (Ipsos, 2008; Jenei, 2012; Canel \& Sanders, 2013).

More recently, there has been a revival of interest in the role of information and communication technologies (ICTs) in local democracy. Mergel has documented research on the use of ICTs in government communication especially the use of social media for interactivity (Mergel, 2017). Mossberger (2013) conducted an empirical study on the use of social media by local government in US cities. He found that social media are mainly used for one-way information provision purposes. A subsequent study by Graham, et al. (2015) discussed the role of social media in local government crisis communications. They found the contrast in the US context, state and local level tweets are dominated by politics more than interaction. Another study by Gao and Lee (2017) have consistently shown that local municipalities adopt social media at significantly lower rates than their state and federal counterparts.

New ICTs have led to a 24-7 government communication practice. Web sites offer limitless amounts of information and opinion to local and global audiences. Citizens in any society can stay better informed about politics and their government. In this context, 
politicians are subject to closer scrutiny by the public in the online environment (Bimber, 2001; Kaid \& Holtz-Bacha, 2008). As indicated from empirical research, the efforts of government agencies to use ICTs tools and applications, Internet and mobile devices to support good governance, strengthen existing relationships and build new partnerships within civil society, are known as e-Government initiatives. E-Government represents the introduction of a great wave of technological innovation as well as government reinvention (Ndou, 2004). It represents a tremendous impetus to move forward in the 21st-century with higher quality, cost-effective government services and a better relationship between citizens and government (Fang, 2002).

Graham and Aurigi explained that many government agencies in developed countries have taken progressive steps toward the web and ICTs use, adding coherence to all local activities on the Internet, widening local access and skills, opening up interactive services for local debates, and increasing the participation of citizens on promotion and management of the territory (Graham \& Aurigi, 1997). Ndou conducted a wide-scale study to identify and analyze the primary issues, opportunities and challenges that e-Government initiatives present for developing countries. The insights and results he presents here are based on empirical, web-based research of 15 case studies undertaken in developing countries (Argentina, Brazil, Chile, China, Colombia, Guatemala, India, Jamaica, the Philippines) which have already explored and implemented e-Government initiatives. In these cases, we can observe different applications and opportunities for e-Government, such as tax administration (Jamaica, Guatemala); better services to customers, businesses and stakeholders in general (Brazil, India); and e-Government for transparency and business efficiency (the Philippines, India, Chile) (Ndou, 2004).

While the adaptive challenges of local government communication actors go far beyond technology, they call for the need for organizational structure and skills, capacity buildings, new forms of leadership, the transformation of public-private partnerships. However, the challenges of local government communication in developing countries remain largely unexplored. In the local context of South Kalimantan, different human agencies, complexities of structural and cultural factors, issues and problems pertaining in this region, requiring focused study and appropriate approach.

In contrast to previous research conducted by other researchers in Western countries, this study seeks to add local context to contribute to the adoption of a local-oriented government communication perspective after the implementation of regional autonomy policy or decentralization in Banjarmasin, South Kalimantan. The term 'government communication' is often used to refer solely to top-level executive communication. But it can also be used to refer to institutions established by the government to do its work at national, regional and local levels (Canel \& Sanders, 2012). This research can also fill the gap in the scarcity of trends in government communication studies that tend to be elitist and nationalcentred actors, with more local-based research. In addition, this research discovers a new concept in dealing with local government communication constraints, namely the Participatory Government Communication Approach.

This study considers the need to introduce a new approach namely participatory government communication approach. This deepens the perspective of participatory development communication. Participatory communication for social change sees people as the nucleus of development (Jacobson \& Servaes, 1998). Therefore, government communication must support development that considers the spirit and culture of the 
community (Servaes, 1999). Based on prerequisites made by previous researchers, this study adds several new prerequisites that are in line with the main objectives of decentralization: responsive, transparent, accountable, and good local government (Aspinall \& Fealy, 2003; Rasyid, 2003). This study offers a preliminary model for Participatory Government Communication Approach for the local context of South Kalimantan where local government communication practices must be responsive, transparent, accountable, open, and involve citizens, which does not mean that all interests have the same impact but that they have a real chance of being articulated and communicated.

This approach is considered adequate to analyze the extent to which Pemda Kalimantan Selatan (the regional government of South Kalimantan) has implemented one or several of the prerequisites. But these preconditions cannot operate in a vacuum, so they need to be placed in the local political and cultural landscape, in this case, the local culture typical of South Kalimantan. This is in line with what Canel and Sanders stated that government communication operates in a multilayered and organizationally diverse environment (Canel \& Sanders, 2013).

\section{METHODOLOGY}

This study uses a qualitative approach to understand the text and the context of local government communication in South Kalimantan. According to Kirk and Miller (1986), a qualitative research approach "fundamentally depends on humans in their territory" (p. 9). Therefore, qualitative research is contextual (Rakhmat \& Ibrahim, 2018, p. 183), so that qualitative researchers in the field of communication, according to Lindlof and Taylor (2002), need to understand the interrelationship between text and the context of communication.

Qualitative research is not only in the form of text as descriptive data on facts. But also the interpretation of facts in socio-cultural settings (the context) (Jensen \& Jankowsky, 1991). The socio-cultural context of the local community needs to be analyzed to provide communication settings for the South Kalimantan regional government. Cultural context analysis includes the use of data and information from studies that rely on the evaluation of secondary material (documents and academic literature).

The context of this research location is Banjarmasin, the capital of Kalimantan Selatan or Kalsel (South Kalimantan) Province. This research was conducted from January to December 2018. The object of this research was the process and communication activities of the South Kalimantan regional government. The focus of the observations was the government communication of public services of the South Kalimantan regional government on the site http://www.kalselprov.go.id; how it functions as a public communication institution to its citizens and the response of key stakeholders to the performance of local government communicators in the communication of public servants in their local government.

Data in this study were collected through in-depth interviews, field notes through observation, and document analysis. In-depth interviews were conducted to take an "inside" perspective with local government officials. While the "outside" perspective was with stakeholders. Stakeholders are parties who are the target of local government communication. Stakeholders consist of various pressure groups that the institution must consider (Kasali, 1994). The selected informants are the key stakeholders related to the local government in South Kalimantan. In-depth interviews were conducted with six strategic informants selected from the backgrounds of government and non-government stakeholders 
to compare various views among the parties, and the interviewees were guaranteed only by the name of the initials (see Table 1 ).

Table 1: Informants for in-depth Interviews

\begin{tabular}{cccc}
\hline No & Informant & Background & $\begin{array}{c}\text { Gender } \\
\text { (F=female; M=male) }\end{array}$ \\
\hline 1. & SH & Non-government & $\mathrm{F}$ \\
2. & SAS & Academics & $\mathrm{F}$ \\
3. & YRM & Government & $\mathrm{M}$ \\
4. & BRW & Political party & $\mathrm{M}$ \\
5. & $\mathrm{~F}$ & Local entrepreneur & $\mathrm{M}$ \\
6. & HS & Local journalist & $\mathrm{M}$ \\
\hline
\end{tabular}

The Data collected (from observations, in-depth interviews, and documents) have been selected, classified and then interpreted in the context of the research location. Documents as secondary material consisting of scientific studies, statistical data, government reports, expert opinions, and related media news. Data that has been interpreted is data that is directly related to the agenda, policies, and communication activities of local government related to public services. The Data is then synthesized with responses from the results of indepth interviews with informants so that data analysis can be done holistically. This is related to the characteristics of qualitative data analysis methods that are more holistic, synthesis, and interpretive (Rakhmat \& Ibrahim, 2018, p. 183).

\section{FINDINGS AND INTERPRETATIONS}

The results of the analysis of the documents carried out seek to explore cultural factors. Cultural aspects denote the orientations, values, and behaviour of both citizens and elites among the people of South Kalimantan. While structural factors will be explored based on observations and in-depth interviews. Structural aspects include institutions building and the application of the rules of the game. Both cultural and structural aspects are closely interrelated and interdependent.

\section{Socio-cultural landscape}

Culture is fluid, constantly changing and adapting according to the responses and dynamics of the community (Ibrahim, 2007 \& 2011). Likewise, the culture that lives in the community in South Kalimantan. Although South Kalimantan is moving into a pluralistic society, the Banjar tribe remains the majority in South Kalimantan. The number reaches 74.3 per cent of the population of South Kalimantan, which amounts to around 4.2 million people (BPS South Kalimantan, 2018). No wonder that Banjar tribal culture with unique characteristics still colours culture and politics in South Kalimantan.

Kalimantan, an island about six times the size of Java, is known as "an island with large rivers". Some of the great rivers split the island and flowed in South Kalimantan Province. Because of the many rivers and streams that flow, the capital city of South Kalimantan, Banjarmasin, is poetically called the "City of a Thousand Rivers". The river has become an important part of the life of the Banjar tribe. 


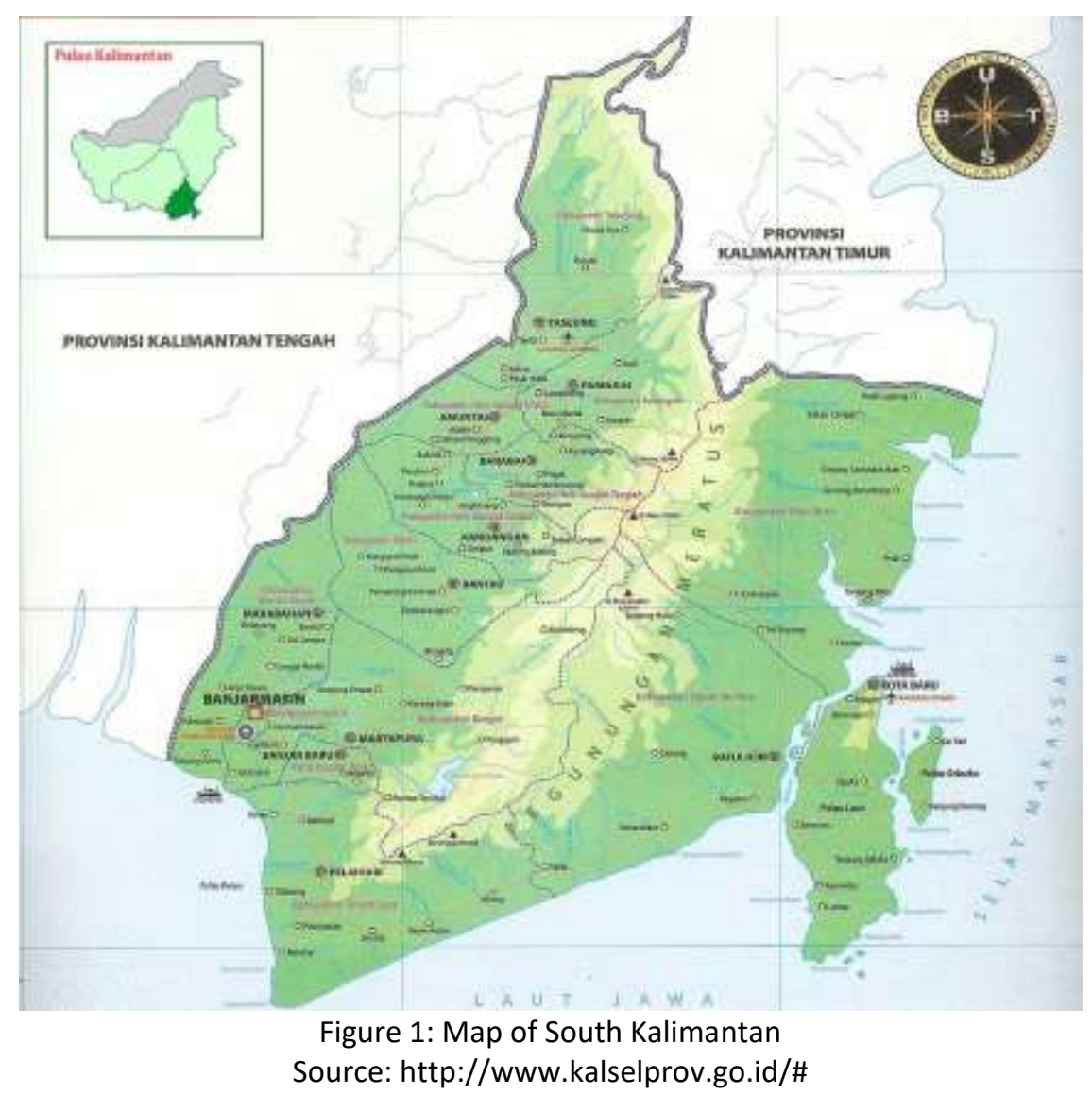

Based on historical records of the culture of this area shows that the development of the Banjar tribe is closely related to the role of rivers in South Kalimantan. River culture is very dominant in shaping the life of Banjar people. The river is a mobility route and a means of transportation for most Banjar people.

The flowing river illustrates endless cultural dynamics and movement. River culture describes the flexibility, life experience, and adaptation of the Banjar tribe to life on the edge or along the riverbanks. This river culture colours all aspects of life including local politics in South Kalimantan. The river plays a role in shaping patterns of social interaction, trade relations, and networks of power in most South Kalimantan communities (Fatchiati, 2009).

According to local cultural experts, on the one hand, river culture is considered to form the Banjar ethnic character as an open society, easy to get along with anyone, and quickly adapt to situations and conditions (Daud, 1997; Mahin, 2004). However, on the other hand, the nature of the tidal river also forms people who live on its banks to be hard fighters in maintaining their lives and lives (Fatchiati, 2009).

In the social life order of the Banjar tribe, the bond with the ulama is also strengthened by the culture of the river (Daud, 2004). It is a means to strengthen what is called "bubuhan", a network of ancestral ties and locality in some Banjar people who migrate upstream or downstream of the river (Daud, 1997).

In contemporary South Kalimantan politics and society, the culture of the river that connects the camps, accompanied by the patron of the ulama, becomes two crucial factors for political parties and legislative candidates who want to win the general election in South Kalimantan. If political parties and candidates are good at interpreting river culture and assembling a network of local and regional ulama patron networks, it will be easier to get support from the people of South Kalimantan. 
The local political culture also affects the preferences of citizens in the election of representatives and the regional head in South Kalimantan. Although local political pragmatism caused a shift in the patterns of support and political relations of the Banjar people. However, adherence to the patronage of "bubuhan" and figures remains the basis of the political attitudes of the majority of the people in the province (Fatchiati, 2009).

\section{Local Government Communication Landscape}

Analysis of the results of in-depth interviews with six key informants and observations on the performance of the official website of the South Kalimantan Regional Government, http://www.kalselprov.go.id/ illustrates a comparison of perspectives from inside and outside relating to local government communication about public services in South Kalimantan.

\section{a. Perspective from Inside (Officeholder)}

Decentralization policy of the Indonesian central government concerning regional autonomy has left hopes and complex challenges for the government and people in regions such as South Kalimantan. Regional autonomy has been implemented in Indonesia through Law No. 22/1999 concerning Regional Government. In 2004, because it was deemed not following the development of the situation, it was replaced with Law No. 32/2004 concerning Regional Government. Furthermore, it has undergone several changes, most recently Law No. 12/2008 concerning the Second Amendment to Law No. 32/2004 concerning Regional Government. For some observers, this is considered an excellent opportunity for local governments to exercise the authority that is a regional right but can also be counterproductive to the reformation movement (Hidayat, 2010). Ideally, centralized, one-way and top-down central government communications are replaced with participatory, two-way and bottom-up local government communications. But the reality is not always in line with reality. 


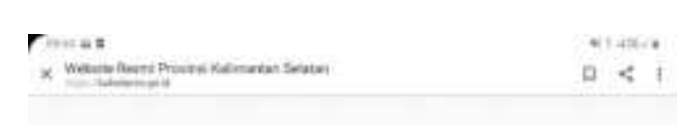

WEBSITE RESMI

PROVINSI KALIMANIAN SELATAN

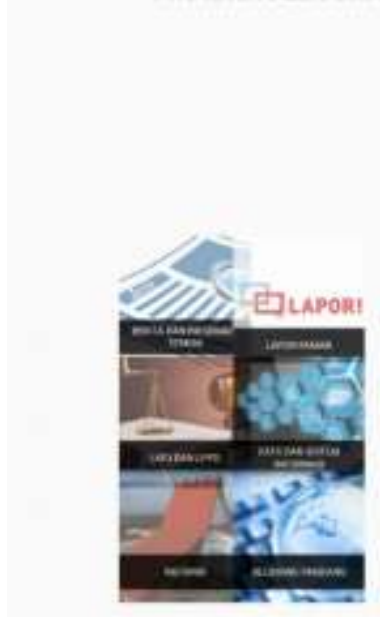

Figure 2: Official website of the regional government of South Kalimantan Province Source: http://www.kalselprov.go.id/

According to information in http://www.kalselprov.go.id, this official website as:

The ideals of the South Kalimantan Provincial Government to develop the South Kalimantan Province as a province that is transparent, accountable, participatory, and innovative. One Data South Kalimantan provides data in an open format and is easily accessed and reused, to increase government transparency and accountability at the same time as encouraging community participation to contribute to the development of the Province of South Kalimantan.

However, although the official website is considered very important in public services, it is only one of the South Kalimantan regional government communication media. Based on field observations and interviews with Informant YRM, there are 12 government 
communication activities carried out by the South Kalimantan Regional Government relating to public services with varying nature of communication (Table 2 ).

Table 2: Media of Local Government Communication in South Kalimantan

\begin{tabular}{llcc}
\hline No. & Media of Communication & Nature of Communication & Key Audience/Stakeholder \\
\hline 1 & Press conference (casuistic) & two-way & journalists \\
2 & Press conference (monthly) & two-way & journalists \\
3 & Advertorial on local media & one-way & journalists \\
4 & Photo lens (diaphragm) & one-way & citizens/public \\
5 & Official Website & one-way & citizens/public \\
6 & Radio Abdi Persada & two-way & citizens/public \\
7 & Abdi Persada Tabloid & one-way & citizens/public \\
8 & Governor's Speech & one-way & citizens/public \\
9 & Interview on TVRI & one-way & citizens/public \\
10 & Collaboration with TV Ambassador \& & one-way & citizens/public \\
& Banjar TV & & journalists \\
11 & Weekly/monthly tabloids & one-way & two-way \\
\hline
\end{tabular}

Source: Data processed by researchers from observation and interview, 2018.

According to Informant YRM, a member of local government officeholder:

Initially, the official website was the Office of Electronic Data Center (PDE) of the South Kalimantan provincial government. However, this unit cannot run optimally. Not all local government policies are published. This website is also not interactive and is not updated regularly so it is not actual. This is because coordination between Local Government Work Units (SKPD) is weak and fellow SKPDs are not mutually open. Admin staff who handle the official website lack skills and competence in analyzing data. Employee competency is still low, unable to make news and analyze it. Public relations management has not run according to its function. In short, there is no clear division of tasks (Informant YRM).

In terms of South Kalimantan regional government communication, the government frequently uses official web and social media for public communication both for public campaigns and public services. Public communication is considered to be a fundamental duty of government officials to constantly update government decisions and actions in order to maintain an informed citizenry. Reports that information provision can be further divided into operational/event information and public service announcements - depending on the characteristics of information provided.

While the use of media of government communication by local government communicators has been highly visible, in the context of South Kalimantan significant questions have been raised over how public agencies themselves.

Based on researchers' observations and interviews, it appears that structural factors greatly influence the quality of government communication services. Among these structural factors are government communicator capacities, government openness, internal coordination between units in local government, management of communication and interaction with key stakeholders and local citizens. 
All of these factors are interrelated to form a top-down approach and one-way government communication style and have not provided a dialogue sphere with keystakeholders who should be local government partners in the development of South Kalimantan society. In addition, the lack of government response to feedback from citizens and stakeholders in terms of the quality of public services shows how the public policies made are not in line with the needs of its citizens. This is a constraint to effective local government communication in supporting regional development.

\section{b. Perspective from Outside (Stakeholders)}

South Kalimantan regional government communication in the form of delivering ideas or programs to the community to achieve common goals (in this case the government can be assumed as a communicator and the community as a communicant). In a dialogical and interactive climate of government communication, the citizen is in a position as a communicator, namely as a sender of ideas and the government is in a position as a communicant who listens to the aspirations of its citizens. In such conditions, citizens have the right to voice access without undermining the authority of the government which is responsible for responding and considering the hopes and needs of the people.

According to Informant HS, a local journalist, citizens want dialogue, unfortunately, the government is not responsive, including with journalists. Informant HS argued that:

For example, previously a monthly press conference was regularly held. Where alternately the SKPD conveys the program, now the intensity is greatly reduced, even almost nonexistent. Services for news requests by journalists depend on the mood of each SKPD head. When contacted, someone did not pick up the phone and dodge. Humas (Public Relations) should act as SKPD representatives explaining the news as a counterweight to the news (Informant HS).

According to Informant F, an entrepreneur, what is needed by local entrepreneurs is transparency and certainty. Informant $F$ argued that:

What is needed is the transparency of regional governments regarding good information services. Yes, like Dispenda who is ready to accept questions, criticisms and suggestions, and respond to the newspaper. Or like UPT Samsat, which provides information services on how much each item costs; how many are paid in full; how much is the rest and others. This shows the existence of transparency and certainty. So, that's what people needs (Informant F).

According to Informant BRW, from local political parties, what is needed is dialogue and interaction. Informant BRW argued that:

Before the South Kalimantan regional government issues a public policy there must be an RDP (Public Discussion Room = public testing). The government invites stakeholders (people related to the policy). Through this RDP there will be input on public policies so that the policies made has broad support from citizens. Unfortunately, all this time the RDP has not been heard, it doesn't 
work. Because there is no media and public input, overlapping programs occur. So far, there has been a condition in which there is a lack of interaction and take and give in the transformation of public policies between local government and the citizens. If the newspaper does not contain criticism of the public policy, then the public cannot know what is happening to the existing policy (Informant BRW).

According to Informant SH, a member of KPU (the General Election Commission) of Banjarmasin City, the local government is unresponsive to women's interests and their problems. Informant SH argued that:

I think the communication of the South Kalimantan provincial government is less responsive to the problem of women in South Kalimantan. Women's voices are also not yet represented in the provincial government's communication policy, although efforts may have been made through various programs. Ensuring communication to the lower classes, education through socialization should not be glamorous and the big reverberations carried out in starred hotels cost of money, but messages do not necessarily reach the lower classes. So make a program that touches on women's issues in the lower classes of society (Informant SH).

According to Informant SAS, a woman academics in Banjarmasin, the government should be able to become a facilitator of openness in strengthening community participation with a gender perspective. Informant SAS argued that:

In general, the state and the government should be a facilitator of public openness and facilitate various regulations and strengthening regulators in the context of community participation with a gender perspective and guaranteeing independence, so that various problems of marginal communities such as women, children, victims of HAM (human rights), labour, fishermen, urban poor, farmers, and disabled as an important issue that must be guarded accompanied by protection and empowerment. Breakthroughs are needed in the government's current public communication strategy given the rapid development of ICTs. The development of ICTs at this time has had a significant impact on the education sector, the economy, to the industry (Informant SAS).

Based on in-depth interviews with the six key-informants and an analysis of the implementation of official channels of the local government communication, it appears that issues related to local government communication in relations with public servants in South Kalimantan. On the one hand, there is dissatisfaction with the implementation of local government communication which is considered not to consider the voices and participation of stakeholders outside the local government. On the other hand, there is recognition from within the local government itself regarding the limited capacity of human resources and management of local government communication channels. 


\section{DISCUSSION}

Discussing local government communication in the context of the South Kalimantan regional government in terms of public services brings the discussion of the role of government and citizens in local democracy. Local democracy requires the active participation of the government and local citizens. This active role found its opportunities in the era of regional autonomy.

The findings of this study indicate that the low capacity of communicator resources and the unprofessional management of local government communication channels causes ineffective communication of public services. Even though effective government communication is needed so that public services are right on target and following the needs of the local community.

In addition, interviews with key-informants outside the local government show that government communication does not yet involve community participation directly related to public policy. Whereas community participation is one of the keys to the success of development communication in the region (Servaes, 1999).

Several prerequisites need to be fulfilled so that local government communication is following the principles of participatory democracy in a context of development communication. In line with that prerequisite, some authors have pointed out the importance of government openness for public engagement (Lee \& Kwak, 2012), to create a culture of transparency (Bertot et al., 2010), transparency in government communication (Fairbanks, Plowman, \& Rawlins, 2007), and political engagement of media and citizens (Dahlgren, 2009). The broader objective of transparency is to ensure that citizens understand how decisions are made and have an opportunity to participate in the decision-making process (Cavoukian \& Mitchinson 2003).

There are two sides to the controversy regarding government communication services, in the era of decentralization and regional democratization in South Kalimantan context, namely; (1) demands that the government provide services to the community; (2) demands government openness and transparency in all public policies. This is illustrated in the results of the interview with key stakeholders from outside the government.

The summary of the results of interviews with key stakeholders illustrates how much the people's expectations are reflected in various opinions regarding various necessities carried out by the South Kalimantan regional government. Although sometimes that necessity seems excessive. But the high hopes also illustrate the irony of decentralization beyond Java. The irony is as seen from the views of the interviewed stakeholders who view that government communication still prioritizes the interests of colleagues and is busy improving itself. "It is not entirely to be more transparent to stakeholders and their citizens," said an informant (HS).

An interactive and responsive local government communication system where the government officeholders always communicate public policies to the public and where people easily access information and provide feedback on various problems they face and policies that are not on target. The ideal conditions of participative government communication like this seem to be still limited to the expectations of stakeholders who are informants in this study.

The role of government communication in local democracy context cannot be separated from the socio-cultural context of the region, and the different communication approaches this generates, ranging from more centralized and elitist forms to more decentralized forms of societal decision-making and problem-solving. To a certain degree, the use of communication technologies plays a significant role, but they are not necessarily 
neutral instruments in the service of government communication. They are always embedded in political constellations and various models of (non-) democratic communication. Moreover, communication technologies are not exclusive driving forces of society, but always part of a broader social context (Carpentier, 2011).

This study shows inspiring results that communication technology through the official web of local government can be an effective government communication media if it facilitates participation and civic engagement. These approaches deal with participation in the media and through the media. Participation through the media focuses on opportunities for participation in public debate, in what some call the public sphere, following a consensusoriented approach (in Habermas concept, 1991) where individual citizens engage in local democratic processes.

Important things that also need to be emphasized that formally successful local government programs should establish responsibility for communication and information dissemination activities and can ask various groups to assist in this process, including local government, civil society organizations or community groups, private sector organizations and the media, to reach the maximum reach among those who need to receive material or participate in communication activities.

This study shows the important thing that is happening in the democratic transition in Indonesia in the 21st century that public expectations of local government communication practices have changed from the role of traditional "officials" to "good partners": caring for citizens, understanding the needs of local communities, and offer solutions to their problems. This is the true meaning of the participatory government communication perspective that must be adopted by local leaders in the context of an archipelago like Indonesia. However, the gap between public expectations of the government as a good partner and public dissatisfaction with their communication performance must be investigated further.

\section{CONCLUSION}

Transitions to democracy in Indonesia is a long-term process that takes decades. Decentralization through national policies on regional autonomy is considered the best way for democratization at the local level where people's voices are heard and people are involved in participatory regional development.

To which extent the local government communication in South Kalimantan involves the participation of its citizens? This study is found that the practices and performance of local government communicators in South Kalimantan are not in line with the expectations of citizens and the demands of legislation where the government is asked to listen to the aspirations of stakeholders and local communities.

In conclusion, the study has helped the researchers to understand that the quality of local government communication was influenced by various factors both cultural and structural. Although local cultural factors remain important, in the case of the South Kalimantan regional government, structural factors have more influence on the government communication implementations in the public services. While government communication does not yet involve active participation from key local stakeholders and their citizens, more elite-oriented or party interests than public-oriented or citizens' interests. The regional government officers are less responsive and still top-down, so the ideas of professionalisation of local government communications are still limited to expectations rather than reality. 
It is probably wise for regional government in South Kalimantan to increase the capacity and quality of government communication services to its citizens via a range of channels, formal and informal. The office-holders need to develop dialogical and transparent local government communication with active involvement by the citizens and to adopt a participatory government communication approach. This study recommends that local government communication can be effective if it has a vision and mission of civic empowerment and citizen engagement in participation for communication planning and its implementation including women's voices and perspectives.

\section{BIODATA}

Bachruddin Ali Akhmad is an Associate Professor in Communication Studies, Fakultas Ilmu Sosial dan Ilmu Politik, Universitas Lambung Mangkurat, Indonesia. Email: bachruddin_aliakhmad@ulm.ac.id 


\section{REFERENCES}

Anderson, B. R. O'G. (1990). Language and power: Exploring political cultures in Indonesia. Ithaca: Cornell University Press.

Antlöv, H. (1995). Exemplary centre, administrative periphery: Rural leadership and the new order in Java. Richmond: Nordic Institute of Asian Studies, Curzon Press.

Aspinall, E., \& Fealy, G. (Eds.) (2003). Local power and politics in Indonesia: Decentralisation and democratization. Singapore: Institute of Southeast Asian Studies.

Bertot, J. C., Jaeger, P. T., \& Grimes, J. M. (2010). Using ICTs to create a culture of transparency: E-government and social media as openness and anti-corruption tools for societies. Government Information Quarterly, 27(3).

Bimber, B. (2001). Information and political engagement in America: The search for effects of information technology at the individual level. Political Research Quarterly, 54(1), 5367.

Buehler, M. (2012). Revisiting the inclusion-moderation thesis in the context of decentralized institutions: The behaviour of Indonesia's prosperous justice party in national and local politics. Party Politics, 19(2).

Buehler, M. (2010). Decentralisation and local democracy in Indonesia: The marginalisation of the public sphere. In Aspinall, E., \& Mietzner, M. (Eds.), Problem of democratisation in Indonesia: Elections, institutions and society. Singapore: Institute of Southeast Asian Studies.

Buehler, M., \& Tan, P. J. (2007). Party-candidate relationships in Indonesian local politics: A case study of the 2005 regional elections in Gowa, South Sulawesi province. Indonesia, 84.

Bünte, M., \& Ufen, A. (eds.) (2009). Democratization in post-Suharto Indonesia. Oxon \& New York: Routledge.

Canel, M. J., \& Sanders, K. (2010). Crisis communication and terrorist attacks: Framing a response to the 2004 Madrid bombings and 2005 London bombings. In Coombs, W. T. \& Holladay, S. J. (Eds), Handbook of crisis communication. Hoboken, NJ: John Wiley \& Sons.

Canel, M. J., \& Sanders, K. (2013). Introduction: Mapping the field of government communication. In Sanders, K. \& Canel, M. J. (Eds.), Government communication: Cases and challenges. London: Bloomsbury.

Canel, M. J., \& Sanders, K. (2012). Government communication: An emerging field in political communication research. In Semetko, H. A. \& Scammell, M. (Eds.) The Sage handbook of political communication. London: Sage.

Canel, M. J., \& Sanders, K. (2014). Is it enough to be strategic? Comparing and defining professional government communication across disciplinary fields and between countries. In Canel, M. J. \& Voltmer, K. (Eds.), Comparing political communication across time and space: New studies in an emerging field. Basingstoke: Palgrave Macmillan.

Canel, M. J., \& Sanders, K. (2011). Government communication. https://doi.org/10.1002/9781405186407.wbiecg033

Carpentier, N. (2011). Media and participation. Chicago: Intellect.

Cavoukian, A., \& Mitchinson, T. (2003). Making municipal government more accountable: The need for an open meetings law in Ontario. IPC Perspectives (October). 
Choi, N. (2004). Local elections and party politics in post-reformasi Indonesia: A view from Yogyakarta. Contemporary Southeast Asia, 26(2).

Coe, K., \& Reitzes, M. (2010). Obama on the stump: Features and determinants of a rhetorical approach. Presidential Studies Quarterly, 40(3), 391-412.

Dahlgren, P. (2009). Media and political engagement: Citizens, communication, and democracy. Cambridge: Cambridge University Press.

Daud, A. (1997). Islam dan masyarakat Banjar: Deskripsi dan analisa kebudayaan Banjar. Jakarta: Rajawali Press.

Daud, A. (2004). Islam dan asal-usul masyarakat Banjar. Kandil, 6(II), August-October.

Deutsch, K. W. (1963). The nerves of government: Models of political communication and control. New York: Free Press.

Fairbanks, J., Plowman, K., \& Rawlins, B. (2007). Transparency in government communication. Journal of Public Affairs, 7(1), 23-37.

Fang, Z. (2002). E-government in the digital era: Concept, practice and development. International Journal of the Computer, 10(2), 1-22.

Farnsworth, S. J. (2009). Spinner in chief: How presidents sell their policies and themselves. Boulder, CO: Paradigm.

Fatchiati, N. (2009). Budaya sungai dan patronase wilayah. Kompas, 17 February.

Fatchiati, N. (2009, June 4). Hasil pemilu Kalimantan Selatan: Kukuhnya patronase ketokohan. Kompas.

Fatchiati, N. (2009, February 17). Peta politik Kalimantan Selatan: Bubuhan, benang merah urang Banjar. Kompas.

Figenschou, T. U., Karlsen, R., Kolltveit, K., \& Thrbjørnsrud, K. (2017). Serving the media ministers: A mixed-methods study on the personalization of ministerial communication. International Journal of Press/Politics, 22(4), 411-430.

Fionna, U. (2011). The pull and push between central and local political parties: A case study of party branch organisation in Indonesia. Asia Pacific Journal of Public Administration, $33(2)$.

Gao, X., \& Lee, J. (2017). E-government services and social media adoption: Experience of small local governments in Nebraska state. Government Information Quarterly, 34(4), 627634.

Geertz, C. (1973). The interpretation of cultures: Selected essays. New York: Basic Books.

Graham, M. W., Avery, E. J., \& Park, S. (2015). The role of social media in local government crisis communications. Public Relations Review, 41(3), 386-394.

Graham, S., \& Aurigi, A. (1997). Virtual cities, social polarisation, and the crisis in urban public space. Journal of Urban Technology, 4(1), 19-52.

Habermas, J. (1991). The public sphere. In Mukerji, C. \& Schudson, M. (Eds.), Rethinking popular culture: Contemporary perspectives in cultural studies. Berkeley/Los Angeles: University of California Press.

Hadiz, V. R. (2003). Power and politics in north Sumatra: The uncompleted reformation. In E. Aspinall \& G. Fealy (Eds.), Local power and politics in Indonesia: Decentralisation and democratisation. Singapore: Institute of Southeast Asian Studies/Leiden: KITLV.

Hadiz, V. R. (2010). Localising power in post-authoritarian Indonesia: A Southeast Asia perspective. Stanford, CA: Stanford University Press.

Hansson, S. (2015). Discursive strategies of blame avoidance in government: A framework for analysis. Discourse \& Society, 26(3), 297-322. 
Hansson, S. (2017). Anticipative strategies of blame avoidance in government: The case of communication guidelines. Journal of Language and Politics, 16(2), 219-241.

Hansson, S. (2018). Government communication. In Wodak, R. \& Forchtner, B. (Eds.), The Routledge handbook of language and politics. London: Routledge.

Hwang, J. C. (2010). When parties swing: Islamist parties and institutional moderation in Malaysia and Indonesia. South-East Asia Research, 18(4). https://doi.org/10.5367/sear.2010.0016

Hidayat, S. (2010). Mengurai peristiwa - merentas karsa: Refleksi satu dasawarsa reformasi desentralisasi dan otonomi daerah. Prisma, 29(3), 3-22.

Hofman, B., \& Kaiser, K. (2002). The making of the big bang and its aftermath: A political economy perspective. Paper presented at the conference 'Can decentralization help rebuild Indonesia?'. Atlanta: Georgia State University.

Hooker, V. M. (Ed.) (1993). Culture and society in new order Indonesia. Kuala Lumpur: Oxford University Press.

Ibrahim, I. S. (2020). Jurnalisme kemiskinan: Representasi kemiskinan di media lokal. Jakarta: Penerbit Buku Kompas.

Ibrahim, I. S., (2007). Kecerdasan komunikasi: Seni berkomunikasi kepada publik. Bandung: Simbiosa.

Ibrahim, I. S., (2011). Kritik budaya komunikasi: Budaya, media, dan gaya hidup dalam proses demokratisasi di Indonesia. Yogyakarta: Jalasutra.

Ipsos MORI. (2008). The reputation of local government: A literature review to support my council campaign. Retrieved on 10 November 2018 from www.ipsos-mori. com/researchpublications/publications/1248/The-reputation-oflocalgovernment.aspx

Jackson, K. D. (1978). The political implications of structure and culture in Indonesia. In Jackson, K. D. \& Pye, L. (Eds.). Political power and communication in Indonesia. Berkeley: University of California Press.

Jacobson, T., \& Servaes, J. (eds.) (1998). Theoretical approaches to participatory communication. Cresskill, NJ: Hampton Press.

Jenei, A. (2012). Communication with the public: From the local government perspective. Budapest: Ad Librum.

Jensen, K. B., \& Jankowsky, N. W. (1991). A handbook of qualitative methodologies for mass communication research. New York: Routledge.

Johansson, K. M., \& Raunio, T. (2019). Government communication in a comparative perspective. In Johansson, K. M. \& Nygren, G. (Eds.) Close and distant: Political executive-media relations in four countries. Göteborg: Nordicom.

Kaid, L. L., \& Holtz-Bacha, C. (Eds.) (2008). Encyclopedia of political communication (Vol. 1). Thousand Oaks, California: Sage.

Kaid, L. L. (Ed.) (2004). Handbook of political communication research. Mahwah, NJ: Lawrence Erlbaum.

Kasali, R. (1994). Manajemen public relations. Jakarta: Grafiti.

Kernell, S. (1997). The theory and practice of going public. In lyengar, S. \& Reeves, R. (Eds.). Do media govern? Politicians, voters and reporters in America. California: Sage.

Kirk, J., \& Miller, M. (1986). Reliability and validity in qualitative research. Newbury Park, CA: Sage. 
Lee, G., \& Kwak, Y. H. (2012). An open government maturity model for social media-based public engagement. Government Information Quarterly, 29(4), 492-503.

Lincoln, Y. S., \& Guba, E. G. (1985). Naturalistic inquiry. Beverly Hills, CA: Sage.

Lindlof, T. R., \& Taylor, B. C. (2002). Qualitative communication research methods (2nd ed.). Thousand Oaks, CA: Sage.

Madinier, R. (2015). Islam and politics in Indonesia: The Masyumi party between democracy and integralism. Singapore: NUS Press.

Mahin, M. (2004). Urang Banjar: Identitas dan etnisitas di Kalimantan Selatan. Kandil, 6(II), August-October.

Mergel, I. (2017). Social media communication modes in government. In Chen, Y.-C. \& Ahn, M.J. (Eds.), Routledge handbook on information technology in government. London: Routledge.

Mietzner, M. (2007). Local elections and autonomy in Papua and Aceh: Mitigating or fuelling secessionism?. Indonesia, 84, 1-39.

Mossberger, K., Wu, Y., \& Crawford, J. (2013). Connecting citizens and local governments? Social media and interactivity in major U.S. cities. Government Information Quarterly, 30(4), 351-358.

Ndou, V. D. (2004). E-government for developing countries: Opportunities and challenges. The Electronic Journal on Information Systems in Developing Countries, 18(1), 1-24.

Noor, F. A. (2014). The Malaysian Islamic party PAS, 1951-2013: Islamism in a mottled nation. Amsterdam: Amsterdam University Press.

Nordholt, H. S. (2004). Decentralisation in Indonesia: Less state, more democracy? In Harriss, J., Stokke, K., \& Törnquist, O. (Eds.), Politicising democracy. The new local politics of democratisation. Houndmills: Palgrave.

Orang Banjar dan budaya sungai. Retrieved on 14 March 2019 from https://5segunda.blogspot.com/2014/04/orang-banjar-dan-budaya-sungai.html

Panuju, R. (2019). Narative analysis of Perindo party advertisement. Jurnal Komunikasi: Malaysian Journal of Communication, 35(3).

Prasetyo, P. S. (2010). Desentralisasi dan demokrasi lokal di Indonesia: Kasus pemerintahan desa di Jawa Barat. In B. S. Hadiwinata S., \& C. Schuck (Eds.). Demokrasi di Indonesia: Teori dan praktik. Yogyakarta: Graha Ilmu.

Pratchett, L. (2004). Local autonomy, local democracy and the "new localism". Political Studies, 52(2), 358-375.

Rakhmat, J., \& Ibrahim, I. S. (2018). Metode penelitian komunikasi: Edisi revisi. Bandung: Simbiosa.

Rasyid, M. R. (2003). Regional autonomy and local politics in Indonesia. In Aspinall, E., \& Fealy, G. (Eds.). Local power and politics in Indonesia: Centralisation and democratization. Singapore: Institute of Southeast Asian Studies.

Salomonsen, H. H., Frandsen, F., \& Johansen, W. (2016). Civil servant involvement in the strategic communication of central government organizations: Mediatization and functional politicization. International Journal of Strategic Communication, 10(3), 207221.

Sanders, K., \& Canel, M. J. (Eds.) (2013). Government communication: Cases and challenges. London: Bloomsbury.

Sanders, K. (2011). Political public relations and government communication. In Strömbäck, J. \& Kiousis, S. (Eds.), Political public relations: Principles and applications. New York: Routledge. 
Sanders, K., Canel, M. J., \& Holtz-Bacha, C. (2011). Communicating governments: A threecountry comparison of how governments communicate with citizens. The International Journal of Press and Politics, 16(4), 523-47.

Servaes, J. (1999). Communication for development: One world, multiple cultures. Cresskill, NJ: Hampton Press.

Spragens, W. G. (2003). New media for the millennium: Federal and state executive press aides and ambition theory. New York: University Press of America.

Supriatma, A. M. T. (2009). Menguatnya kartel para "bos". Prisma, 28(2).

Suryadinata, L. (2002). Elections and politics in Indonesia, Singapore: Institute of Southeast Asian Studies.

Tomsa, D. (2010). The Indonesian party system after the 2009 elections: Towards stability? In Aspinall, E. \& Mietzner, M. (Eds.). Problems of democratisation in Indonesia: Elections, institutions and society. Singapore: ISEAS.

Törnquist, O. (2013). Popular aspirations, decentralisation and local democracy. In Öjendal, J. \& Dellnäs, A. (Eds.), The imperative of good local governance: Challenges for the next decade of decentralization. Tokyo: United Nations University Press.

Ufen, A. (2011). Direct local elections and the fragmentation of party organization in Indonesia. APSA 2011 Annual Meeting Paper.

Vos, M., \& Westerhoudt, E. (2008). Trends in government communication in the Netherlands. Journal of Communication Management, 12(1).

Wahid, U. (2013). Perempuan dan kekuasaan politik dalam pemilukada DKI Jakarta tahun 2012. Jurnal Komunikasi: Malaysian Journal of Communication, 29(1).

Walcott, C. E., \& Hult, K. M. (2008). George Akerson's legacy: Continuity and change in White House press operations. Presidential Studies Quarterly, 38(4), 593608.

Wan Norshira Wan Mohd Ghazali. (2019). Islam as the state ideology: Exploring from Gramsci's notion of power, culture and ideology. Jurnal Komunikasi: Malaysian Journal of Communication, 35(1).

Young, S. (Ed.) (2007). Government communication in Australia. Cambridge: Cambridge University Press. 